\title{
Identifying high noise levels with possible health implications at building façades for five crossroads in Tirana, Albania
}

\author{
Kuenda Laze ${ }^{1, *}$ \\ ${ }^{1}$ Polytechnic University of Tirana, Faculty of Civil Engineering, Department of Environmental \\ Engineering, Rr. "M. Gjollesha", No. 54, 1023 Tirana, Albania \\ *Corresponding Author: K Laze (m1.laze@ outlook.com)
}

\begin{abstract}
Road traffic in crossroads increases noise levels in Tirana. This study demonstrates the inhabitants' perceptions on noise using questionnaires and noise level predictions at building façades using three different speed roads and four ranges of building heights, and applying the Nordic Prediction Method for five crossroad urban areas of Tirana. Nordic Prediction Method was applied to calculate: (1) basic noise for high and low speed roads, (2) noise levels for outside receivers at building façade in crossroad neighbourhoods. A quarter of respondents (out of 36) perceived to get sick due to high noise levels, and at least one respondent in every crossroads perceived their crossroad environments associated with high noise levels. Outside receivers (imaginary receivers or inhabitants) at building façades located at crossroads and close to high speed roads were exposed to high noise levels exceeding the national and the WHO community noise standards of $55 \mathrm{dBA}$ for daytime. Speeds of vehicles and locations of buildings in crossroad neighbourhoods contributed to noise levels at building façades. This study identified high noise level areas that can be further investigated in terms of long-term effects of high noise levels on population health in Tirana.
\end{abstract}

Keywords: building façade; crossroads; health; Nordic Prediction Method; outside receivers; Tirana

\section{Introduction}

One environmental management task is traffic noise control (Cai and Liu, 2011) to keep noise levels below or equal to domestic standards in urban areas. High noise levels put at risk human health, e.g. hypertension and ischaemic heart disease (World Health Organization, 1999; Ndrepepa and Twardella, 2011; World Health Organisation Regional Office for Europe and Joint Research Centre, 2011; van Kempen and Babisch, 2012), adversely affecting performance of cognitive tasks for workers and children (World Health Organization, 1999), behavioural and sleeping problems for children (Ndrepepa and Twardella, 2011), causing to low performance of, e.g. pupils and teachers (Chetoni et al., 2016), and to annoyance of population (OUIS, 2001; Jakovljevic, Paunovic and Belojevic, 2009; Ndrepepa and Twardella, 2011). Low frequency sounds with a range between $10 \mathrm{~Hz}$ and $200 \mathrm{~Hz}$ are considered an environmental noise problem in outdoor environment (Persson and Rylander, 1988) contributing also to a higher number of psycho-social symptoms, sleep 
disturbance, headaches and annoyance (Persson and Björkman, 1988; Persson and Rylander, 1988).

Crossroads are commonly built in urban areas. They can be roundabouts or signalized intersections, which are two forms of road junctions, with complex traffic flow and varying state of vehicle motion (Cai and Liu, 2011). Road junctions (crossroads) are usually occupied by large traffic volume composed of light and heavy vehicles. Vehicles in acceleration or deceleration can produce audible unpleasant sounds and high noise levels (World Health Organization, 1999; World Health Organisation Regional Office for Europe and Joint Research Centre, 2011) (above 65 A-weighted decibel; dBA) as well as low frequency sounds (van Kempen and Babisch, 2012). Low frequency sounds are distinguished by efficient propagation reducing the efficacy of dwellings and walls (Ndrepepa and Twardella, 2011) of buildings located at heavy traffic roads and or crossroads.

Vehicles change their speeds (acceleration/deceleration) when entering and exiting a crossroad. Cai and Liu (2011) has found that acceleration and deceleration of vehicles in crossroads affected vehicle noise emission, and both roundabouts and signed intersections (crossroads) showed different patterns of noise distributions with noise energy of the exit lane being greater than noise energy of the entrance lane. Noise energy produced by vehicles was expected to negatively affect people living particularly in poorly acoustically isolated buildings (low quality of acoustic isolation material and or no acoustic isolation material used), which were close to a crossroads (main road junctions). Tenailleau et al. (2016) showed that the number of buildings, average noise level and $\mathrm{NO}_{2}$ diffusion increased with decreasing distance to the nearest main road indicating that road traffic (vehicles) were one of the major environmental pollution sources in a European middle size urban area of Besançon in France. Davies et al. (2009) have found a positive correlation between noise and nitrogen dioxide $\left(\mathrm{NO}_{2}\right)$ and nitrogen oxides $\left(\mathrm{NO}_{\mathrm{X}}\right)$ concentrations emitted from motor vehicles in traffic (including intersections or crossroads). Tenailleau et al. (2016) also found a significant and positive correlation between noise levels and $\mathrm{NO}_{2}$ exposure estimates for building façades.

Road junctions (crossroads) are surrounded by buildings, which can be exposed to high noise levels in urban areas. For example, high noise levels were found near the main roads and highway (high-speed roads) in Palma de Mallorca (Spain) with a substantial number of people of 99 percent of population being exposed to above $55 \mathrm{dBA}$ (Ausejo et al., 2011). For London, 12 percent (1.03 million people) were exposed to daytime road traffic noise levels $\geq 65 \mathrm{dBA}$, alone (Gulliver et al., 2015).

High noise levels due to road traffic were measured in five crossroads (Laze, 2017) presenting major urban road junctions in the capital city of Tirana. The study area was identified as high noise level areas by governmental bodies (Institute of Public Health, 2013), which monitored environmental noises in Tirana. In this paper, sound propagation (without distinguishing between high frequency sounds above $200 \mathrm{~Hz}$ and low frequency sounds between $10 \mathrm{~Hz}$ and $200 \mathrm{~Hz}$ ) was estimated at building façade at five crossroads of the central part of the urban area of $2.28 \mathrm{~km}^{2}$ of Tirana, Albania. Vehicle sounds were assumed to be the dominant sounds for the study area. These sounds were expected to negatively affect inhabitants in buildings located around five crossroads. Specifically, it was calculated: (1) 
basic noise for high and low speed roads, (2) noise levels for outside receivers at building façades located in crossroad neighbourhoods by applying the Nordic Noise Prediction method in ArcGIS 10.3 (Environmental Systems Research Institute, 2016). Finally, we collected the latest available measurements of $\mathrm{NO}_{2}$ (nitrogen dioxide) emissions from vehicles in the year 2012 conducted by the governmental bodies for five crossroads and perceptions of inhabitants on noises at five crossroads in Tirana.

The aim was to firstly collect information on inhabitants' perception on noise and noise related health implications and to secondly identify the variation in noise levels at building façades for five crossroads neighbourhoods for Tirana.

We note here that there is a growing evidence of road traffic noise associated with cardiovascular diseases (Babisch, 2011; Ndrepepa and Twardella, 2011; Davies and Kamp, 2012; Münzel et al., 2014) and noise annoyance (OUIS, 2001; Ndrepepa and Twardella, 2011; van Kempen and Babisch, 2012). Noise annoyance is considered as one of the first and most widespread human reactions to environmental noise affecting inhabitants' wellbeing (OUIS, 2001) and cardiovascular diseases are one of the ten most common diseases in Albania (www.who.int/countries/alb). We hypothesized that adults (inhabitants) were exposed to high noise levels exceeding $55 \mathrm{dBA}$ during daytime at crossroads (neighbourhoods) in Tirana. We set a threshold of $55 \mathrm{dBA}$ for a healthy inhabitant in terms of noise exposure, excluding duration of exposure and any natural (e.g. age, gender) and socioeconomic factor (e.g. employment status) affecting the inhabitant health. No risk and an increased risk of cardiovascular disease and noise annoyance was respectively assumed for an inhabitant exposed to road traffic noise below and exceeding $55 \mathrm{dBA}$.

Table 1: Hypothesis on noise annoyance and cardiovascular diseases for population in Tirana based on existing estimations on associations between road traffic high noise levels exceeding $55 \mathrm{dBA}$ and population health in cities

\begin{tabular}{|c|c|c|c|}
\hline Hypothesis & Health data & Estimations data & References \\
\hline $\begin{array}{l}\text { Inhabitants } \\
\text { exposed to high } \\
\text { noise levels } \\
\text { exceeding } 55 \mathrm{dBA} \\
\text { could have an } \\
\text { increased risk for } \\
\text { being annoyed }\end{array}$ & No data & $\begin{array}{l}\text { Identified increased risk for } \\
\text { high level of noise (daytime } \\
\text { Leq=61.66 } \pm 5.84 \mathrm{dBA} \text { ) } \\
\text { annoyance with regard to } \\
\text { orientation of living room to the } \\
\text { street, duration of stay at } \\
\text { apartment and noise sensitivity } \\
\text { in Belgrade }\end{array}$ & $\begin{array}{l}\text { (Jakovljevic, } \\
\text { Paunovic and } \\
\text { Belojevic, 2009) }\end{array}$ \\
\hline $\begin{array}{l}\text { Inhabitants } \\
\text { exposed to high } \\
\text { noise levels } \\
\text { exceeding } 55 \mathrm{dBA} \\
\text { could be at risk for } \\
\text { a cardiovascular } \\
\text { disease }\end{array}$ & $\begin{array}{l}59 \text { percent is the } \\
\text { proportionality of } \\
\text { population mortality } \\
\text { for all ages and both } \\
\text { sexes in Albania (this } \\
\text { is a proxy percent } \\
\text { data for population in } \\
\text { Tirana) }\end{array}$ & $\begin{array}{l}\text { Identified a positive and } \\
\text { significant association between } \\
\text { road traffic noise above } 60 \mathrm{dBA} \\
\text { and hypertension e.g. in Scảnia } \\
\text { region in Sweden and a (slight) } \\
\text { increased risk of cardiovascular } \\
\text { disease in urban populations } \\
\text { exposed to road traffic noise } \\
\text { with noise levels between } 45 \\
\text { and } 75 \mathrm{dBA} \text {, worldwide. }\end{array}$ & $\begin{array}{l}\text { (Ndrepepa and } \\
\text { Twardella, 2011; } \\
\text { Davies and Kamp, } \\
\text { 2012; van Kempen } \\
\text { and Babisch, 2012; } \\
\text { Münzel et al., } \\
\text { 2014); } \\
\text { www.who.int }\end{array}$ \\
\hline
\end{tabular}


The hypothesis on effects of high noise levels in Tirana on population health based on the existing knowledge are summarized in Table 1.

\section{Materials and Methods}

\subsection{Questionnaire}

A questionnaire was prepared by the author for education purposes, in compliance with the program of the Polytechnic University of Tirana and with the consent of participants (inhabitants and students). The questionnaire was composed of nine questions concerning the inhabitants' perception on noise at crossroads (feeling disturbed by noises, willing to leave the house due to road noises, indoor noise reduction measurements), noise related health implications (being disturbed by noises, noise related health implications, inhabitants' perception on noises in Tirana, being informed about noise related health implications) and general questions (inhabitants, house location). In total, approximately 33, 45, 22 percent of questions were respectively related to inhabitants' perception on noises at crossroads, noise related health implications and general questions (Appendix A).

Since the five crossroads were identified as high noise level areas (by governmental bodies), then, questionnaires and noise level measurements were undertaken to collect information on noise levels and inhabitants' perceptions at crossroads and their neighbourhoods. The questionnaires were manually filled in by the master students of Polytechnic University of Tirana at crossroads from 8:30 until 13:00 in November 2015 and November 2016 (Figure 1). All questionnaires were anonymous. Respondents were adults (male and female above 18 years old). Students also measured noise levels (A-weighted equivalent sound pressure levels, $\mathrm{LA}_{e q, \mathrm{t}}$ ) at the same day of the questionnaires were compiled resulting, in total, to approximately 1000 values of noise levels for five crossroads in the year 2015 and 2016. Noise level measurements are not reported in this study. For more information on this educational exercise see Laze (2017).

\subsection{Roads and buildings data}

The study area is the area inside the five crossroads, which are numbered from 1 to 5 in Figure 1.

The study area is a low-lying area. We did not considered elevation data in calculating noise level estimations assuming an entirely flat area for the study area. We also assumed a building story to be $3.1 \mathrm{~m}$ (e.g. Farcaş, 2008). We estimated noise levels (for outside receivers) at a building (façade) height considering 1-the highest story (e.g. at third floor building façade for a three story-building) and 2- the lowest story (at first floor building façade) for all buildings. Roads and buildings were aligned and clipped with the boundary of urban area of Tirana, (Figure 1). Road and building data (of the year 2017) respectively utilized for the calculations of basic road noise and outside receivers (imaginary receivers (persons) staying outside buildings at each $2 \mathrm{~m}$ height from each other) at building façade using ArcGIS 10.3 were provided by the OpenStreetMap (OpenStreetMap Contributors, 2017). Road data contained road types and road maximum speed for every road type. Road type and road maximum speed, which were selected for this analysis, were respectively 
"primary", residential", "secondary", "tertiary", "motorway" with road maximum speed of 60 $\mathrm{km} / \mathrm{h}, 30 \mathrm{~km} / \mathrm{h}, 40 \mathrm{~km} / \mathrm{h}, 30 \mathrm{~km} / \mathrm{h}$ and $120 \mathrm{~km} / \mathrm{h}$, (Figure 1).

Figure 1. Study area in Tirana (a) showing the road network and outside receivers at the closest single building façade to the nearest crossroad within a radius of $200 \mathrm{~m}$ from a crossroad location. Photos of five crossroads are: 1- a roundabout, 2-5- signed intersections. Photos are taken on 17 and 18 June 2017 by the author. (b) Location of study area in Tirana urban area and (c) location of Tirana.
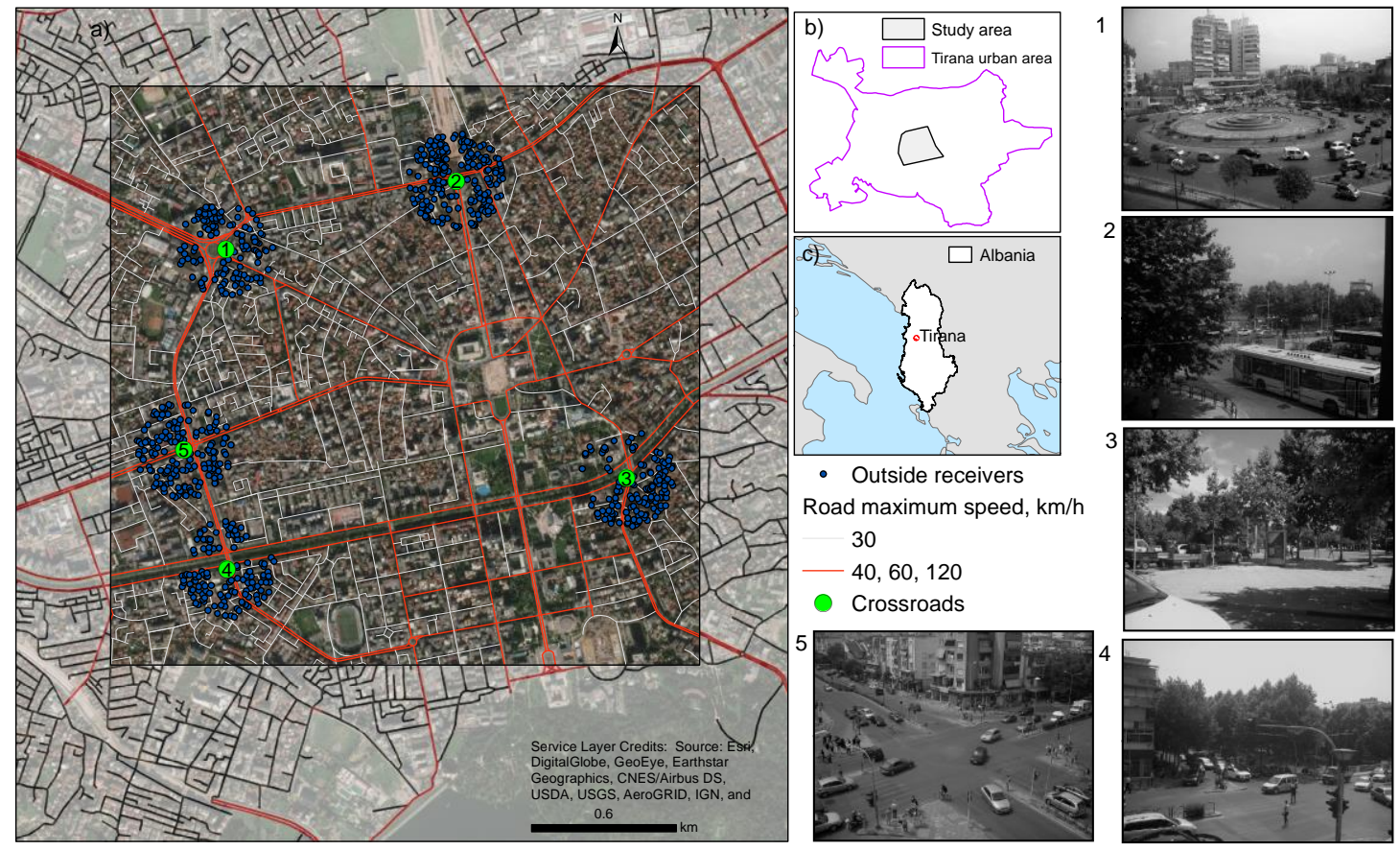

Roads with a speed above $30 \mathrm{~km} / \mathrm{h}$ i.e. "primary", "secondary", and "motorway" presented high speed roads (henceforth "high-speed roads"). "Residential" and "tertiary" roads with a speed of $30 \mathrm{~km} / \mathrm{h}$ were considered as low speed roads (henceforth "low-speed roads"). Low-speed roads ("residential" and "tertiary" category roads) and high-speed roads ("primary" and "secondary" excluding "motorway" category roads) composed, respectively, 82.8 percent and 16 percent of all roads.

Building shape data of the year 2017 were completed by building shape data of the year 2007 provided by the Pineridge Group, Inc., (2007). The data of the year 2007 ranged buildings heights between: 1) one and three stories, 2) four and six stories, 3) seven and ten stories, and 4) above ten stories. New buildings constructed between 2007 and 2017 were digitalized using satellite images of Google Earth. These new buildings height data were entered by using Google Earth satellite images and personal observations. Buildings between one and three stories and between four and six stories respectively composed 89 percent and 8 percent of 34120 buildings.

\subsection{Nordic Prediction Method}

The Nordic Prediction Method was published by the Nordic Council of Ministers (Nielsen, 1997) for mapping of road and railway noise in the year 2006 and it has been used for calculating road and railway noise starting from the year 2007 (eng.mst.dk). The method 
can be used for calculation of noise levels $\left(\mathrm{L}_{\text {Aeq }}\right.$; $\left.\mathrm{dB}\right)$ over 24 Hours (Bendtsen, 1999) for each road or section of road assuming no strong wind and moderate temperature (which were introduced as wind and temperature correction in the year 2000 by the Advance Noise Prediction), and for a distance up to $300 \mathrm{~m}$ far from the road (Farcaş, 2008). Accordingly, the distance from 0 to $300 \mathrm{~m}$ and above $300 \mathrm{~m}$ is respectively assumed to affect and not affect population.

Steps of noise level calculations include as follows: (1) basic road noise level $\mathrm{L}_{1}$ was a function of speed $v$ and the number of light and heavy vehicles (2) distance correction $\Delta \mathrm{L}_{2}$ presented the change of noise regarding distance considering the distance to road, height of the road $(0.5 \mathrm{~m})$ and height of receiver, (3) ground and barrier collection $\Delta \mathrm{L}_{3}$, considered the effect of screening and of the ground (soft like grass) and hard (like concrete), (4) other corrections $\Delta \mathrm{L}_{4}$ included (4.1) angle of view, which was the angle of view from the receiver contributed to overall sound pressure level, and (4.2) thick screen correction and (5) façade corrections $\Delta \mathrm{L}_{5}$ related to building construction materials (Farcaş, 2008). The basic road noise and corrections were calculated for each road or section of road and then for entire road based on the Equation (1) as follows:

$$
\mathrm{L}_{\text {Aeq }}=\mathrm{L}_{1}+\Delta \mathrm{L}_{2}+\Delta \mathrm{L}_{3}+\Delta \mathrm{L}_{4}+\Delta \mathrm{L}_{5}
$$

$\mathrm{L}_{\text {Aeq }}$ for each road or section of the road was then summed up (from $i=1$ to $n$ ) for entire road based on Equation 2 as follows:

$$
\mathrm{L}_{\text {Aeq }}=10 \lg \left(\Sigma 10^{\mathrm{LAeqi} / 10}\right)
$$

The Nordic Prediction Method was used for analysing the basic road noise in the Skảne region and Lund commune in Sweden (Farcaş, 2008; Farcaş and Sivertunb, 2009). Farcaş, (2008) calculated noise levels with corrections between $\mathrm{L}_{1}$ and $\mathrm{L}_{4}$, (1) for different receiver heights (with a step height of $2 \mathrm{~m}$ ) in 3D, (2) population exposure to noise by sex, age and count with a given dBA and (3) noise levels for building façades using road type, speed limits for roads, building shape, population location by making assumptions for missing data of building heights, road traffic flow (the number of light and heavy vehicles in 24 hours), terrain elevation, road gradients and ground type data. The height of a receiver and of a road was respectively assumed 1.6 and $0.5 \mathrm{~m}$ from the ground (Farcaş, 2008). Noise calculation at building façades was used to buffer each building by a given distance and generated observer points for each segment of the buffer area (polygon) (Farcaş, 2008).

Chang et al. (2012) used the Nordic Prediction Method to map road traffic noise in Taichung City, Taiwan by adding local data such as types of traffic flow rates (heavy vehicles, light vehicles and motorcycles), speed roads and road characteristics, height of buildings, type of ground and location of the receiver relative to the surrounding road surface or barriers, and found a significant correlation (0.75) between predicted and measured noise levels. The modified Nordic Prediction Model was found applicable for estimating noise levels of Taichung city (Chang et al., 2012).

\subsection{Basic road noise and noise calculations for building façade}

Logarithmic average values of noise level were firstly calculated for "primary", "residential", "secondary", tertiary", "motorway" roads, respectively. LAeq was a function 
of the number of light and heavy vehicles and their speed limits using the Equations one and two making assumptions on the number of light and heavy vehicles (excluding the number of motors because motors are rarely used in Tirana). For the basic road noise calculations and assumptions concerning the number of light and heavy vehicles see Laze (2017).

Basic road noise calculations for roads ( $\mathrm{L}_{1}$ in Equation one) were the first step of noise calculations. A buffer zone (polygon) of $2 \mathrm{~m}$ (from a building façade) was created for every building to calculate noise at building façades. The buffer zone helped to randomly select outside receivers (point data) outside buildings (at building façade) for each building. Two outside receivers (Figure 2) were randomly selected (separated by $5 \mathrm{~m}$ from each other) for each building resulting to a total of 68240 outside receivers.

Figure 2: The example of the selection of outside receivers at building façade. The buffer area of $2 \mathrm{~m}$ around a building is in teal colour. Outside receivers are in light green colour. Source: Pineridge Group, Inc. (2007) and Google Earth 2017.

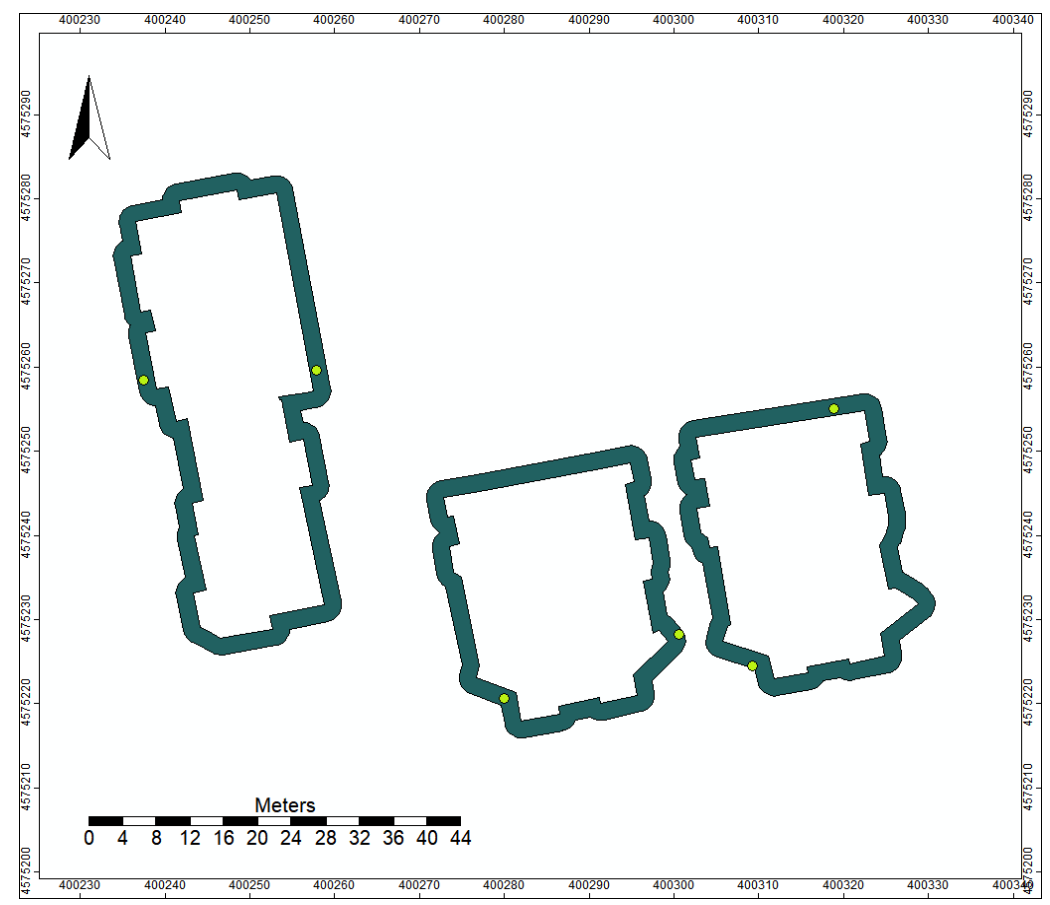

The noise level at building façade, which is the function of a vehicle speed, the number of light vehicles and heavy vehicles and changes of noise due to distance, angle of view of the outside receiver, effects of soft ground (which was assumed as the main ground in the study area e.g. trees surrounding roads) and building thickness (façade corrections $\left(\Delta \mathrm{L}_{5}\right.$ in Equation 1) was excluded because of no data on building materials) was calculated. Changes in noise level namely distance corrections $\Delta \mathrm{L}_{2}$ (Equation three), screen correction and soft ground $\Delta \mathrm{L}_{3}$ (Equations four and fove), angle of view and thickness $\Delta \mathrm{L}_{4}$ (Equations six and seven) were added to the basic road noise $\mathrm{L}_{1}$ in Equation one. Equations from 3 to 7 are shown in Appendix B.

The height of a receiver and a road was respectively 1.6 and $0.5 \mathrm{~m}$ from the ground. The geographic coordinates $(\mathrm{X}, \mathrm{Y})$ and azimuth were calculated for every outside receiver to estimate the direction angle of the roads. Distance between building and outside receiver was 
calculated using straight-line distance of each outside receiver from the closest road (i.e. from either high speed or low speed roads) resulting to a raster. A value of this raster was extracted for every outside receiver to find the distance of the outside receiver from the nearest road assuming that high speed roads were nosier than low speed roads. The basic noise calculation for roads was summed up with correction of angle of view, soft ground, screen and thickness for every outside receiver.

To investigate the role of the distance between a building and a receiver, three distance values of $0.5 \mathrm{~m}, 0.8 \mathrm{~m}$ and $2 \mathrm{~m}$ were respectively used for calculating a screen correction, $\Delta \mathrm{L}_{3}$. Heights of outside receivers at building façade (outside buildings) were calculated for each $2 \mathrm{~m}$ height starting from receiver height of $1.6 \mathrm{~m}$.

Results of noise calculations for outside receivers (height of $1.6 \mathrm{~m}$ ) and outside receivers at building façade of heights of $9.6 \mathrm{~m}, 17.6 \mathrm{~m}, 19.6 \mathrm{~m}$ and $29.6 \mathrm{~m}$ were interpolated using inverse distance weighted interpolation (IDW) assuming the measured values (outside receivers) closest to the prediction location have more influence on the predicted value than those farther away from the measured values (outside receivers) (Environmental Systems Research Institute, 2016). Interpolated noise levels estimations were then used to produce noise distribution map to identify high noise levels (above a threshold value associated with possible noise-related health implications) and non-high noise levels areas (below the threshold value associated with no noise-related health implications). High noise level and non-high noise levels were selected by assuming an average outdoor noise level of $55 \mathrm{dBA}$ (the threshold value of noise-related health implications) of national and the World Health Organization (WHO) community noise standards in residential areas (World Health Organization, 1999; Gulliver et al., 2015; Tenailleau et al., 2016) for daytime.

Figure 3: The percentage of responses on inhabitants' perceptions on noise at crossroads, noise related health implications and inhabitants' perception on noises in Tirana. Questions are 1, 3, 4, 5, 6 and 8. Responses are 1,2, 4 and 5 for the year 2015. Responses are 2, 3 and 4 with an asterisk for the year 2016. The questions and responses are shown in Appendix C. The questionnaire is in Appendix A.

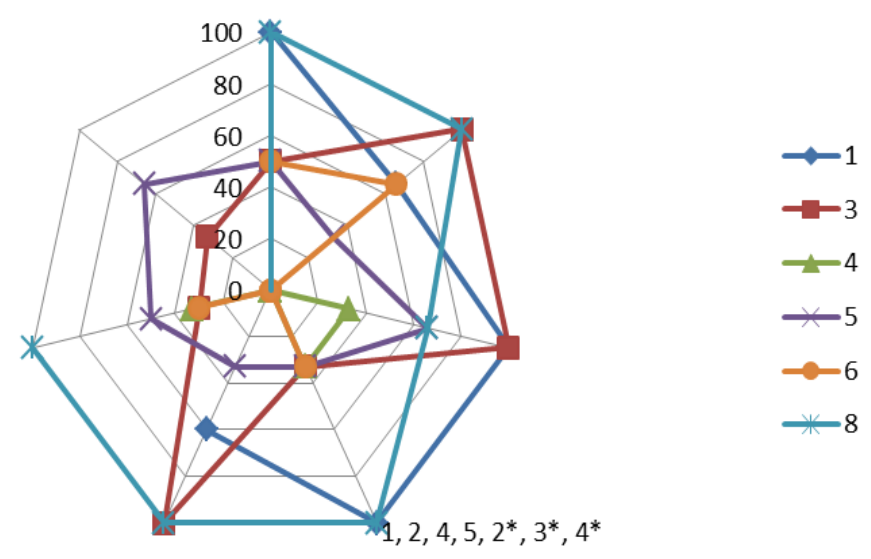




\section{Results}

\subsection{Perception of inhabitants}

Respondents were inhabitants, workers, students or pedestrians (question one). At least one respondent in every crossroads evaluated the crossroad as "noisy" indicating that inhabitants perceived their crossroad environments associated with high noise levels (question three). The 33 percent of respondents were willing to leave their neighbourhoods near crossroads four and five due to high level noises (question four). In average, approximately half and a quarter of respondents had respectively taken noise reduction measurements in their homes (built before the year 1990; question five) and perceived to get sick (worse) due to high noise levels (question six). Respondents experienced noise annoyance, frustration, and communication interruption due to high noise levels at the crossroad two (Appendix C). Most of respondents (66 and 100 percent in Figure 3) highlighted the presence of high noise levels in Tirana (question eight). Noise level measurements of crossroads largely exceeded $55 \mathrm{dBA}$ (73 and 100 percent) varying between 48 and $101 \mathrm{dBA}$ for the year 2015 and 2016 (Appendix D).

\subsection{Noise distribution}

There were respectively 65 percent and 27 percent of buildings within $300 \mathrm{~m}$ and 100 $\mathrm{m}$ far from these roads. In total, 87.6 percent and 99.7 percent of buildings were respectively within a radius of $50 \mathrm{~m}$ and $300 \mathrm{~m}$ far from any road types. Thus, there were no calculations for distance correction.

Patterns of estimated average logarithmic noise levels (noise distribution) for two outside receivers at a single building façade slightly changed for every 34120 buildings with heights between $3.6 \mathrm{~m}$ and $29.6 \mathrm{~m}$ (maps from (a) to (e) in Figure 4). The average logarithmic value of basic noise levels for roads was $56.8 \mathrm{dBA}$, map (f) of Figure 4. Spaces around crossroads and high-speed roads (roads with noise levels > $65 \mathrm{dBA}$; Figure 4) had high noise levels exceeding outdoor noise level of $55 \mathrm{dBA}$ of national and the WHO community noise standards in residential areas for daytime. High noise level roads exceeding the threshold of $55 \mathrm{dBA}$ were respectively approximately $68 \mathrm{dBA}, 70 \mathrm{dBA}, 76$ $\mathrm{dBA}, 73 \mathrm{dBA}$, and $64 \mathrm{dBA}$ for crossroads from 1 to 5 shown in map (f) of Figure 4 . The mean difference between the predicted and measured noise levels of the year 2015 and 2016 respectively changed (in absolute terms) from 3.3 to $16.5 \mathrm{dBA}$ and from 0.58 to $17.5 \mathrm{dBA}$ (Appendix D). Areas between buildings and around low-speed roads obtained non-high noise levels of below $55 \mathrm{dBA}$. Outside receivers at building façades located at crossroads and close to high speed roads were exposed to high noise levels of above the threshold of 55 dBA. Approximately 25 percent of outside receivers at building façades located to the nearest high speed roads (estimated average logarithmic noise levels $>65 \mathrm{dBA}$ in maps (a-f) of Figure 4), were exposed to high noise levels above the threshold of $55 \mathrm{dBA}$ of national and WHO community noise standards during daytime.

Figure 4. Maps of estimated average logarithmic noise level using basic road noise and corrections (Equation 1) for outside receivers at a building façade with a height of: (a) 29.6 
m, (b) $19.6 \mathrm{~m}$, (c) $17.6 \mathrm{~m}$, (d) $9.6 \mathrm{~m}$, (e) $3.6 \mathrm{~m}$. Map of estimated average logarithmic noise level using basic road noise for basic road noise without correction calculations, outside receivers (point data in blue colour shown for demonstration) within a radius of $200 \mathrm{~m}$ far from a crossroad and $\mathrm{NO}_{2}$ measurements (the number at the centre of circles in green colour) of the year 2012 are in (f).
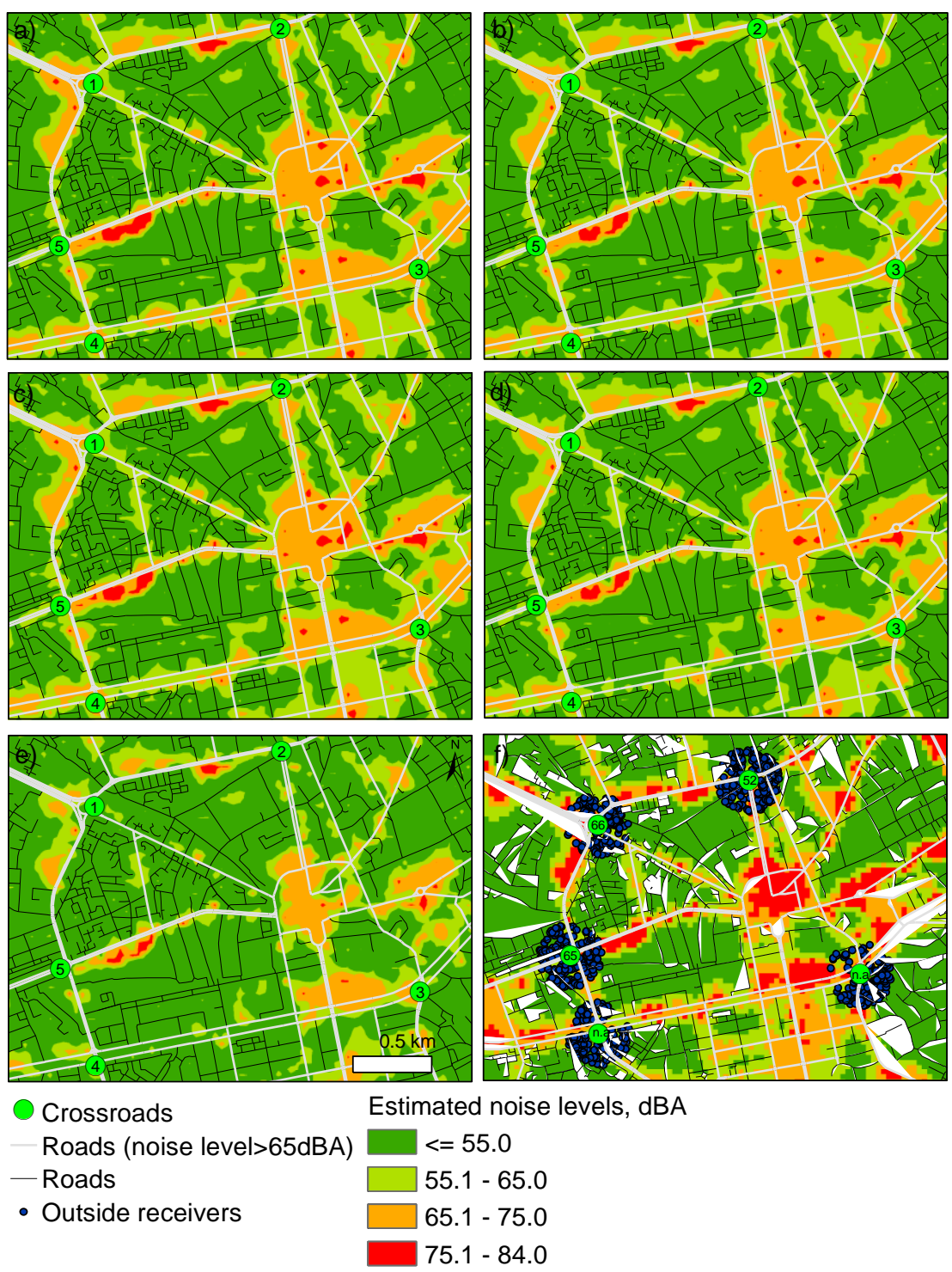

In total, 26 percent of outside receivers at building façades located to the nearest crossroads (i.e. within a radius of $200 \mathrm{~m}$ far from a crossroad) and or to the nearest highspeed roads, as shown in map (f) of Figure 4, were exposed to high noise levels of above 55 dBA. Outside receivers at building façades located between buildings and close to low speed roads were not exposed to high noise levels (below the threshold of $55 \mathrm{dBA}$ ).

\section{Discussion}

This study showed that crossroads and high-speed roads had an estimated noise levels above $55 \mathrm{dBA}$ exceeding the national and the WHO community noise standards in residential areas during daytime. Noise levels measurements indicated high noise levels by 73 percent 
of all measurements for five crossroads in the year 2015 and 2016 (Appendix D). All respondents of crossroads respectively mentioned that high noise levels were an environmental problem and a quarter of respondents perceived to get worse (e.g. noise annoyance) due to high noise levels attributed to road traffic. These findings support our assumptions that inhabitants at crossroads were exposed to high noise levels exceeding 55 $\mathrm{dBA}$ and potentially associated with an increased risk of noise annoyance and cardiovascular diseases in populations.

Respondents could identify health outcomes such as noise annoyance frustration, and communication interruption, but not cardiovascular diseases attributed to high noise levels. Yet, noise annoyance is the primary (health) outcome that is used to evaluate the effect of noise on communities indicating also a poorer quality of life (Clark and Stansfeld, 2007; Clark, Head and Stansfeld, 2013) affecting inhabitants' well-being (OUIS, 2001). Jakovljevic et al. (2009) found that noise annoyance showed strong correlation with noise levels, personal (individual) characteristics and housing conditions in the urban area of Belgrade. In Madrid, Tobías et al. (2015) found an association between diurnal noise levels $\left(\mathrm{L}_{e q} \mathrm{D}\right)$ exposure and mortality for both cardiovascular and respiratory diseases (causes) caused by both high noise levels and PM2.5 levels (air pollution) for population of age above 65 years old. In this line, three crossroads (1, 2, 5 in map (f) of Figure 4) showed high concentration of $\mathrm{NO}_{2}$ exceeding European standard of $40 \mu \mathrm{gr} / \mathrm{m}^{3}$ (annual averaged $\mathrm{NO}_{2}$ in microgram $/ \mathrm{m}^{3}$ ) (Tenailleau et al., 2016), which were measured by a governmental body (Institute of Public Health, 2013) (the latest available data of $\mathrm{NO}_{2}$ ). This data indicated that 60 percent of crossroads (of this study) were source of air pollution in residential areas of Tirana causing likely health outcomes (e.g. cardiovascular diseases) on population along with high noise levels (see e.g. Davies and Kamp, 2012). The Nordic Prediction Method approach using spatial data of buildings and roads was used to calculate basic noise calculations for roads and corrections like distance correction, angle of view correction, screen and screen ground correction and thickness correction (see Materials and Methods), with screen ground correction as the major correction of basic noise calculations for roads. Noise calculations (the basic noise calculations for roads and corrections) were based on road traffic noise, obtaining noise distributions for crossroads, high-speed roads and low-speed roads. Noise distribution patterns shown in Figure 4 changed clearly between low-speed roads (low vehicle flow, low vehicle speed) and high-speed roads (high vehicle flow, high vehicle speed) as well as between buildings located close to low-speed roads and buildings located close to high-speed roads and crossroads. The results obtained by this study divided central part of urban area of Tirana into high noise levels (above $55 \mathrm{dBA}$ ) and non-high noise level areas (below $55 \mathrm{dBA}$ ) identifying outside receivers that were exposed to either high or low noise levels. Low noise level areas were located between buildings and in low-speed roads. High noise levels were concentrated in areas around high-speed roads and crossroads meaning that outside receivers at building façades close to crossroads and high-speed roads were exposed to high noise levels (Figure 4) with possible noise-related health implications (Table 1). 


\subsection{Limitations}

We lacked data on time-series of noise measurements and health implications attributed to high noise levels for population of Tirana. Further limitations are a lack of data on building materials, road materials and height, number of light and heavy vehicles for 24 hours and studies about dose-response relationship between affected population and high noise levels (see Jakovljevic, Paunovic and Belojevic, 2009) in Tirana, about health impact assessment concerning cardiovascular diseases (see Tobías et al., 2015), which are the first cause of life lost for population in Albania and potentially in Tirana. The questionnaire was designed for education purposes and was limited to a small number of samples and nine questions without a point scale response (e.g. 1, 2, 3), which could be used for an advance statistical analysis.

\subsection{Strengthens and future work}

This study showed the readiness of inhabitants to participate in noise assessment surveys. Inhabitants highlighted that high noise levels exceeding $55 \mathrm{dBA}$ were an environmental problem and linked their health decline to high noise levels. This study identified the areas of estimated high noise levels (> $55 \mathrm{dBA}$ ) and found a correlation between the estimated basic road noises and noise level measurements in the year 2015 and 2016 (Pearson correlation coefficients were respectively 0.50 and 0.58). The areas of estimated high noise levels can be further investigated in terms of long-term effects of high noise levels on population health such as noise annoyance, cardiovascular disease, and wellbeing. Studies on traffic-related pollution and cardiovascular disease to investigate any correlation between air and noise pollution and cardiovascular disease could also be important (Davies et al., 2009) not only in Tirana but also in other large urban areas in Southeastern Europe for comparison and for filling existing gaps in literature. New estimations on noise levels using Directive 2002/49 (END) and new studies on low frequency sound (background noise produced by vehicles in traffic) and on infrasound (sounds below $20 \mathrm{~Hz}$ ) that are present in high noise outdoor environments could be beneficial in terms of health population protection.

\section{Conclusions}

Crossroads were found to be source of noise pollution and most likely of air pollution in Tirana. Seasonal measurements (winter, summer) of air pollutants as $\mathrm{NO}_{2}$ and noise levels in crossroads should be regularly monitored and published by responsible governmental bodies. Effects of road traffic noise can be investigated in depth to help elaborate underlying factors of noise annoyance and cardiovascular diseases attributed to high noise levels for all ages and genders in Tirana.

\section{Acknowledgements}

I am grateful to three anonymous reviewers for their comments on this manuscript. 


\section{References}

Ausejo, M., Tabacchi, M., Recuero, M., Asensio, C., Pagán, R. and Pavón, I. (2011) 'Design of a noise action plan based on a road traffic noise map', Acta Acustica united with Acustica. S. Hirzel Verlag, 97(3), pp. 492-502. doi: 10.3813/AAA.918429.

Babisch, W. (2011) 'Cardiovascular effects of noise', Noise and Health, 13(52), pp. 201-204. doi: $10.4103 / 1463-1741.80148$.

Bendtsen, H. (1999) 'The Nordic prediction method for road traffic noise', Science of The Total Environment, 235(1), pp. 331-338. doi: https://doi.org/10.1016/S0048-9697(99)002168.

Cai, M. and Liu, J. (2011) 'Dynamic simulation and characteristics analysis of traffic noise at signal-controlled pedestrian crossing junction’, Applied Acoustics, 59(July), pp. 549-555. doi: 10.1016/j.apacoust.2017.01.026.

Chang, T.-Y., Lin, H.-C., Yang, W.-T., Bao, B.-Y. and Chan, C.-C. (2012) 'A modified Nordic prediction model of road traffic noise in a Taiwanese city with significant motorcycle traffic.', The Science of the total environment. Netherlands, 432, pp. 375-381. doi: 10.1016/j.scitotenv.2012.06.016.

Chetoni, M., Ascari, E., Bianco, F., Fredianelli, L., Licitra, G. and Cori, L. (2016) 'Global noise score indicator for classroom evaluation of acoustic performances in LIFE GIOCONDA project', Noise Mapping, p. 157. doi: 10.1515/noise-2016-0012.

Clark, C., Head, J. and Stansfeld, S. A. (2013) 'Longitudinal effects of aircraft noise exposure on children's health and cognition: A six-year follow-up of the UK RANCH cohort', Journal of Environmental Psychology, 35, pp. 1-9. doi: https://doi.org/10.1016/j.jenvp.2013.03.002.

Clark, C. and Stansfeld, S. A. (2007) 'The Effect of Transportation Noise on Health and Cognitive Development: A Review of Recent Evidence', International Journal of Comparative Psychology, 20, pp. 145-158. doi: 10.5811/westjem.2011.5.6700.

Davies, H. and Kamp, I. Van (2012) 'Noise and cardiovascular disease: a review of the literature 2008-2011.', Noise \& health. India, 14(61), pp. 287-291. doi: 10.4103/14631741.104895.

Davies, H. W., Vlaanderen, J. J., Henderson, S. B. and Brauer, M. (2009) 'Correlation between co-exposures to noise and air pollution from traffic sources', Occupational and Environmental Medicine, 66(5), pp. 347-350. doi: 10.1136/oem.2008.041764.

Environmental Systems Research Institute (2016) ArcGIS 10.3. http://www.esri.com. Available at: http://www.esri.com.

Farcaş, F. (2008) Road Traffic Noise: A study of region Skåne, Sweden. Master Thesis, . Linköping University. ISRN: LIU-IDA/FFK-UP-A--08/015--SE. Available at: http://urn.kb.se/resolve?urn=urn:nbn:se:liu:diva-17786.

Farcaş, F. and Sivertunb, ̊. (2009) Road traffic noise: GIS tools for noise mapping and a case study for Skåne region. The International Archives of the Photogrammetry, Remote Sensing and Spatial Information Sciences, Vol. 34, Part XXX. Available at: www.isprs.org/proceedings/XXXVIII/2-W11/Farcas_Sivertun.pdf (Accessed: 26 November 2016).

Gulliver, J., Morley, D., Vienneau, D., Fabbri, F., Bell, M., Goodman, P., Beevers, S., Dajnak, D., J Kelly, F. and Fecht, D. (2015) 'Development of an open-source road traffic 
noise model for exposure assessment', Environmental Modelling \& Software. Elsevier Ltd, 74, pp. 183-193. doi: 10.1016/j.envsoft.2014.12.022.

Institute of Public Health (2013) Annual Report of Air Quality, Tirana 2012 (in Albanian). Available at: http://www.ishp.gov.al/multimedia/raporti_vjetor_i_cilesise_se_ajrit.pdf. (Accessed: 10 June 2017).

Jakovljevic, B., Paunovic, K. and Belojevic, G. (2009) 'Road-traffic noise and factors influencing noise annoyance in an urban population', Environment International, 35(3), pp. 552-556. doi: http://dx.doi.org/10.1016/j.envint.2008.10.001.

van Kempen, E. and Babisch, W. (2012) 'The quantitative relationship between road traffic noise and hypertension: a meta-analysis.', Journal of hypertension. England, 30(6), pp. 10751086. doi: 10.1097/HJH.0b013e328352ac54.

Laze, K. (2017) 'Findings from measurements of noise levels in indoor and outdoor environments in an expanding urban area: a case of Tirana', Noise Mapping, 4(1), p. 45. doi: 10.1515/noise-2017-0003.

Münzel, T., Gori, T., Babisch, W. and Basner, M. (2014) 'Cardiovascular effects of environmental noise exposure', European Heart Journal, 35(13), pp. 829-836. Available at: http://dx.doi.org/10.1093/eurheartj/ehu030.

Ndrepepa, A. and Twardella, D. (2011) 'Relationship between noise annoyance from road traffic noise and cardiovascular diseases: a meta-analysis.', Noise \& health. India, 13(52), pp. 251-259. doi: 10.4103/1463-1741.80163.

Nielsen, H. L. (1997) Road Traffic Noise: Nordic Prediction Method. Stationery Office (Temanord Series). Available at: https://books.google.al/books?id=icliN15oFPUC.

OpenStreetMap Contributors (2017) Planet dump retrieved from https://planet.osm.org. Available at: http://download.geofabrik.de/.

OUIS, D. (2001) 'ANNOYANCE FROM ROAD TRAFFIC NOISE: A REVIEW', Journal of Environmental Psychology, 21(1), pp. 101-120. doi:

https://doi.org/10.1006/jevp.2000.0187.

Persson, K. and Björkman, M. (1988) 'Annoyance due to low frequency noise and the use of the $\mathrm{dB}(\mathrm{A})$ scale', Journal of Sound and Vibration, 127(3), pp. 491-497. doi:

http://dx.doi.org/10.1016/0022-460X(88)90374-4.

Persson, K. and Rylander, R. (1988) 'Disturbance from low-frequency noise in the environment: A survey among the local environmental health authorities in Sweden', Journal of Sound and Vibration, 121(2), pp. 339-345. doi: http://dx.doi.org/10.1016/S0022460X(88)80034-8.

Pineridge Group Inc. (2007) Buildings. Available at: https://www.tpginc.net/gis/albania (Accessed: 23 January 2017).

Tenailleau, Q. M., Bernard, N., Pujol, S., Parmentier, A. L., Boilleaut, M., Houot, H., Joly, D. and Mauny, F. (2016) 'Do outdoor environmental noise and atmospheric NO2 levels spatially overlap in urban areas?', Environmental Pollution, 214, pp. 767-775. doi: 10.1016/j.envpol.2016.04.082.

Tobías, A., Recio, A., Díaz, J. and Linares, C. (2015) 'Health impact assessment of traffic noise in Madrid (Spain)', Environmental Research, 137, pp. 136-140. doi:

https://doi.org/10.1016/j.envres.2014.12.011. 
World Health Organisation Regional Office for Europe and Joint Research Centre (2011) Burden of disease from environmental noise. Quantification of healthy life years lost in Europe. Available at: www.euro.who.int/_data/assets/pdf_file/0008/.../e94888.pdf (Accessed: 3 July 2017).

World Health Organization (1999) WHO Guidelines for community noise. Available at: http://www.who.int/docstore/peh/noise/guidelines2.html (Accessed: 19 November 2014). 


\section{Supplementary material}

Appendix A: The questionnaire

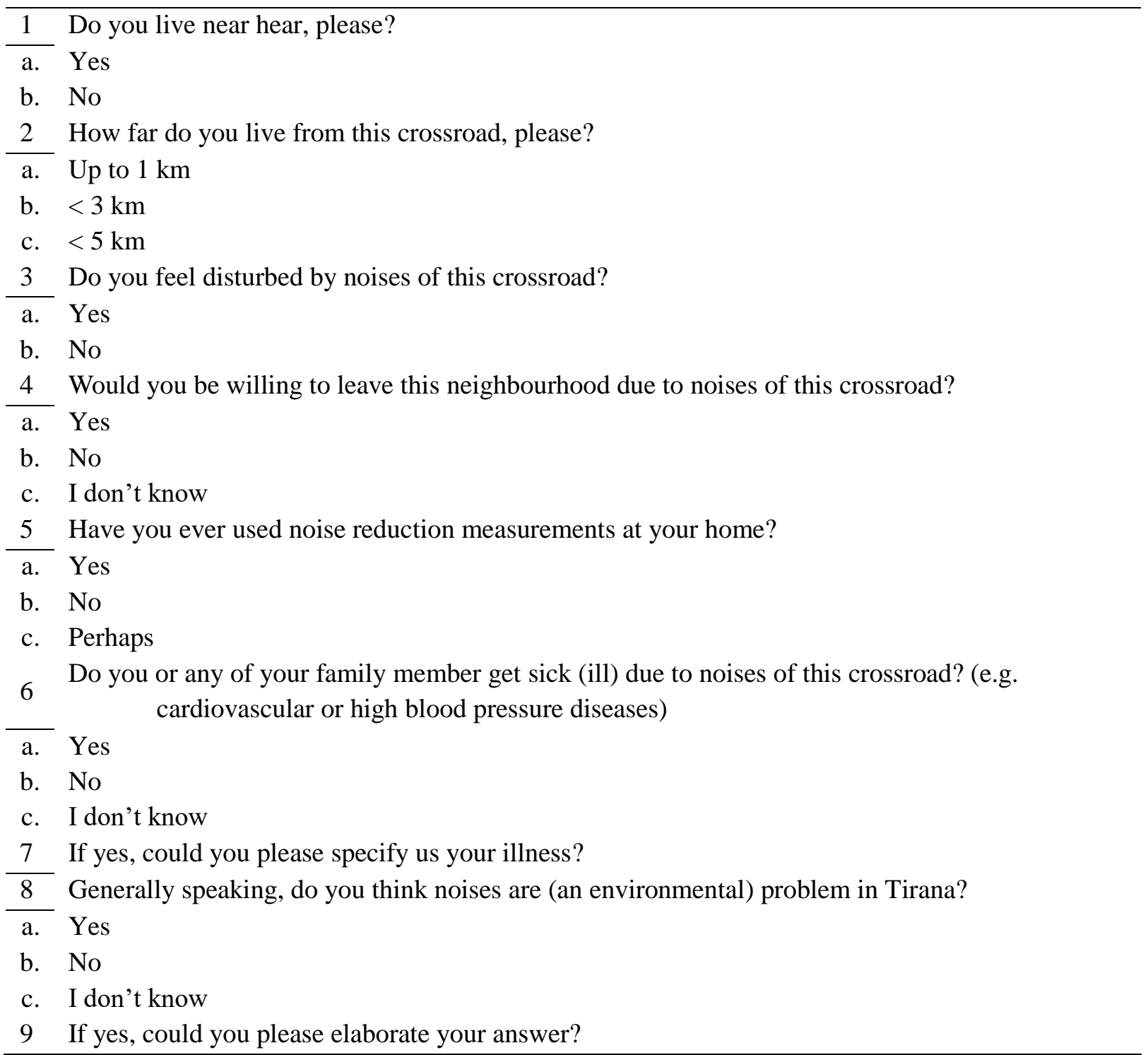

Appendix B: Equations

Equations of distance correction $\Delta \mathrm{L}_{2}(\Delta \mathrm{L}$ in page 21$)$, of screen correction and soft ground $\Delta \mathrm{L}_{3}\left(\Delta \mathrm{Ls}\right.$ in page 22,23 and $\mathrm{L}_{m}$ in page 23$)$, of angle of view and thickness $\Delta \mathrm{L}_{4}\left(\Delta \mathrm{L}_{\alpha}\right.$ in page 24 and $\Delta \mathrm{L}_{t s}$ in page 25) for noise level at building façade following Farcaş (2008) are as follows:

Correction of distance, $\Delta \mathrm{L}_{2}: \Delta L_{2}=-10 \lg \left[\frac{\sqrt{a^{2}+\left(h_{m}-h_{b}-0.5\right)^{2}}}{10}\right.$,

where $a=$ distance along the normal to the road (distance from receiver perpendicular to road); $h_{b}=$ height of the road $(0.5 \mathrm{~m})$ and $h_{m}=$ height of the receiver 
Correction of screen correction $\Delta \mathrm{L}_{3}: \Delta L_{3}=-25$ for $x \geq 2.4$;

$\Delta L_{3}=-5-10 \lg \left(1+x+17 x^{2}\right)$ for $0 \leq x \leq 2.4 ; \Delta L_{3}=-5+10 \lg (1-x+$ $17 x^{2}$ ) for $-0.33 \leq x \leq 0$;

$\Delta L_{3}=0$ for $x<-0.33,(4)$

where $x=1.1 h_{e} \sqrt{\frac{d_{2}+d_{1}}{d_{1} d_{2}}} ; d_{1}=$ distance from a noise source to a building; $d_{2}$

$=$ distance from the building to a receiver; $h_{e}$

$=\frac{\left(h_{v}-h_{m}\right) d_{1}+\left(h_{v}-h_{b}-0.5\right) d_{2}}{\sqrt{\left(d_{1}+d_{2}\right)^{2}}+\left(h_{m}-h_{b}-0.5\right)^{2}}$

Correction of soft ground, $\mathrm{L}_{3}$ :

$\Delta L_{3}=-4 z \lg (\sigma)$ for $0.3<\sigma<1 ; \Delta L_{3}=2 z-4 z \lg \left(\frac{0.3}{\sigma}\right)$ for $0.1<\sigma<0.3 ; \Delta L_{3}=$ 0 for $\sigma \leq 0.1$;

$\sigma=\frac{d_{2} X 10^{-0.3 h_{v}}}{10 h_{m}}$

Correction of angle of view $\Delta \mathrm{L}_{4}: \Delta L_{4}=10 \lg \left(\frac{\pi}{180}\right),(6)$

where $\alpha=$ the angle of view for a (outside) receiver

Correction of thickness $\Delta \mathrm{L}_{4}: \Delta L_{4}=-k \lg 2.2(e-0.05)$, if $\Delta L_{4}>0$ then $\Delta L_{4}=0 ;(7)$

$k=11-10^{(6-u)} / 6 ; u=\frac{3.5+V_{s}+V_{m}-\sqrt{100+V_{s}^{3}+V_{m}^{3}-1.6 V_{s} V_{m}+7\left(V_{s}+V_{m}\right)}}{18} ;$

$V_{s}=\arctan \left(\frac{h_{v}-h_{b}-0.5}{d_{1}}\right)$ where $\theta_{k}=90^{\circ}+V_{s}$ and $V_{m}=\arctan \left(\frac{h_{v}-h_{m}}{d-d_{1}-e}\right)$ where

$\theta_{m}=90^{\circ}+V_{m}$ and $\mathrm{e}=$ thickness of a building and $\mathrm{e}>1.5 \mathrm{~m}$

Appendix C: The summary of results of affirmative responses ("yes") obtained from questionnaires for crossroads from one to five in the year 2015 and 2016 in Tirana. There 
were respectively no data available for crossroads three, one and five in the year 2015 and 2016.

\begin{tabular}{|c|c|c|c|c|c|c|c|c|c|c|}
\hline & \multicolumn{5}{|c|}{ Year 2015} & \multicolumn{5}{|c|}{ Year 2016} \\
\hline $\begin{array}{l}\text { Number of } \\
\text { respondents }\end{array}$ & 2 & 3 & 3 & 3 & 3 & 3 & 3 & 10 & 3 & 3 \\
\hline & \multicolumn{10}{|c|}{ The percentage of affirmative ("yes") responses } \\
\hline $\begin{array}{l}\text { Questions/ } \\
\text { crossroads }\end{array}$ & 1 & 2 & 3 & 4 & 5 & 1 & 2 & 3 & 4 & 5 \\
\hline $\begin{array}{l}\text { 1. Do you live } \\
\text { near hear, } \\
\text { please? }\end{array}$ & $\begin{array}{l}10 \\
0\end{array}$ & 66 & n.a & n.a. & 100 & n.a & 100 & 60 & n.a. & n.a \\
\hline $\begin{array}{l}\text { 2. How far do } \\
\text { you live from } \\
\text { this crossroad, } \\
\text { please? }\end{array}$ & $\begin{array}{l}10 \\
0\end{array}$ & 66 & n.a & n.a. & 100 & $\begin{array}{l}\text { n.a } \\
\text {. }\end{array}$ & 100 & 50 & n.a. & n.a \\
\hline $\begin{array}{l}\text { 3. Do you feel } \\
\text { disturbed by } \\
\text { noises of this } \\
\text { crossroad? }\end{array}$ & 50 & 100 & n.a & 100 & 33 & n.a & 100 & 30 & 33 & n.a \\
\hline $\begin{array}{l}\text { 4. Would you } \\
\text { be willing to } \\
\text { leave this } \\
\text { neighbourhood } \\
\text { due to noises } \\
\text { of this } \\
\text { crossroad? }\end{array}$ & 0 & 0 & n.a & 33 & 33 & n.a & n.a. & 0 & 33 & n.a \\
\hline $\begin{array}{l}\text { 5. Have you } \\
\text { ever used } \\
\text { noise } \\
\text { reduction } \\
\text { measurements } \\
\text { at your home? }\end{array}$ & 50 & 33 & n.a & 66 & 33 & n.a & 33 & 50 & 66 & n.a \\
\hline $\begin{array}{l}\text { 6. Do you or } \\
\text { any of your } \\
\text { family } \\
\text { member get } \\
\text { sick (ill) due } \\
\text { to noises of } \\
\text { this crossroad? }\end{array}$ & 50 & 66 & n.a & 0 & 33 & n.a & 0 & 30 & 0 & n.a \\
\hline $\begin{array}{l}7 . \text { If yes, could } \\
\text { you please } \\
\text { specify us } \\
\text { your illness? }\end{array}$ & n.a. & $\begin{array}{l}\text { Frustration } \\
\text { High blood } \\
\text { pressure; sleep } \\
\text { disturbance }\end{array}$ & n.a & none & n.a. & n.a & $\begin{array}{l}\text { non } \\
\mathrm{e}\end{array}$ & n.a. & $\begin{array}{l}\text { non } \\
\mathrm{e}\end{array}$ & n.a \\
\hline $\begin{array}{l}\text { 8. Generally } \\
\text { speaking, do } \\
\text { you think } \\
\text { noises are (an } \\
\text { environmental } \\
\text { ) problem in } \\
\text { Tirana? }\end{array}$ & $\begin{array}{l}10 \\
0\end{array}$ & 100 & n.a & 66 & 100 & n.a & n.a. & $\begin{array}{l}10 \\
0\end{array}$ & 100 & n.a \\
\hline 9. If yes, could & n.a. & Because (high & n.a & Busy & n.a. & n.a & n.a. & n.a. & n.a. & n.a \\
\hline
\end{tabular}




\begin{tabular}{lll} 
you elaborate & level) noises & road \\
your answer? & cause & traffic; \\
& communicatio & vehicles \\
& n interruption, & \\
noise & \\
annoyance for & \\
inhabitants & \\
particularly & \\
children and & \\
& old people. & \\
\hline
\end{tabular}

Appendix D: The percent of noise level measurements above $55 \mathrm{dBA}$, the minimum and maximum measured noise levels and the mean difference between predicted basic road noise and noise level measurements (in $\mathrm{dBA}$ ) for crossroads from one to five in the year 2015 and 2016. There is no data available for noise measurements at crossroad five for the year 2016. Crossroads from one to five are shown in Figure 4.

\begin{tabular}{|c|c|c|c|c|c|c|c|c|}
\hline \multirow[t]{2}{*}{$\begin{array}{c}\text { Crossroa } \\
\mathrm{ds} \\
\end{array}$} & \multicolumn{4}{|c|}{ Year 2015} & \multicolumn{4}{|c|}{ Year 2016} \\
\hline & $\begin{array}{l}\text { The } \\
\text { percent of } \\
\text { noise level } \\
\text { measureme } \\
\text { nts }>55 \\
\text { dBA }\end{array}$ & $\begin{array}{l}\text { Minimu } \\
\mathrm{m} \\
\text { measur } \\
\text { ed } \\
\text { noise } \\
\text { level, } \\
\text { dBA }\end{array}$ & $\begin{array}{l}\text { Maxim } \\
\text { um } \\
\text { measure } \\
\text { d noise } \\
\text { level } \\
\text { dBA }\end{array}$ & $\begin{array}{l}\text { Mean } \\
\text { differen } \\
\text { ce, dBA }\end{array}$ & $\begin{array}{l}\text { The } \\
\text { percent of } \\
\text { noise level } \\
\text { measureme } \\
\text { nts }>55 \\
\text { dBA }\end{array}$ & $\begin{array}{l}\text { Minimu } \\
\mathrm{m} \\
\text { measur } \\
\text { ed } \\
\text { noise } \\
\text { level, } \\
\text { dBA }\end{array}$ & $\begin{array}{l}\text { Maxim } \\
\text { um } \\
\text { measure } \\
\text { d noise } \\
\text { level } \\
\text { dBA }\end{array}$ & $\begin{array}{l}\text { Mean } \\
\text { differen } \\
\text { ce, dBA }\end{array}$ \\
\hline 1 & 100 & 62.4 & 84.1 & -3.3 & 100 & 56 & 101 & -14.2 \\
\hline 2 & 73 & 48 & 77.7 & 9 & 100 & 56 & 88.4 & -0.58 \\
\hline 3 & 100 & n.a. & n.a. & 9.5 & 100 & 55.6 & 68.7 & 17.5 \\
\hline 4 & 100 & 67.2 & 88.8 & -2.5 & 100 & 67 & 89 & -2.5 \\
\hline 5 & 100 & 66 & 99.3 & -16.5 & n.a. & n.a. & n.a. & n.a. \\
\hline
\end{tabular}

